Marquette University Law School

Marquette Law Scholarly Commons

Faculty Publications

Faculty Scholarship

$1-1-2007$

\title{
The Impact of Popular Culture on American Perceptions of the Courts
}

David Ray Papke

Marquette University Law School, david.papke@marquette.edu

Follow this and additional works at: http://scholarship.law.marquette.edu/facpub

Part of the Law Commons

Publication Information

David Ray Papke, The Impact of Popular Culture on American Perceptions of the Courts, 82 Ind. L.J. 1225 (2007)

\section{Repository Citation}

Papke, David Ray, "The Impact of Popular Culture on American Perceptions of the Courts" (2007). Faculty Publications. Paper 134. http://scholarship.law.marquette.edu/facpub/134

This Article is brought to you for free and open access by the Faculty Scholarship at Marquette Law Scholarly Commons. It has been accepted for inclusion in Faculty Publications by an authorized administrator of Marquette Law Scholarly Commons. For more information, please contact 


\title{
The Impact of Popular Culture on American Perceptions of the Courts
}

\author{
DAVID RAY PAPKE*
}

\section{INTRODUCTION}

Lengthy service as a judge or in law enforcement sometimes makes a person a bit paranoid. After sixteen years on the bench, The Honorable Patricia D. Marks, the Supervising Judge for the Criminal Courts in New York's Seventh Judicial District, worried that pop cultural works might be affecting the jurors in her courtroom. ${ }^{1}$ Hollywood films, she thought, could make potential jurors leery of serving. Television shows could influence the jurors' understanding of their role. ${ }^{2}$ Was Judge Marks being unduly concerned? She perhaps asked herself that very question. But then, after working to guarantee her jurors were not biased by popular culture, she saw an Internet posting from a man who had been summoned for jury duty and actually was doing his "homework" by watching Jury Duty (1995), Trial By Jury (1994), and 12 Angry Men (1957). ${ }^{3}$

For jurors in other courtrooms and for average citizens as well, it seems likely that popular culture affects what they think of the courtroom and courtroom proceedings. In the first section of this essay, I proffer a definition of popular culture and raise the question of how we might study its impact. In the second section, I present a short overview of the way portrayals of the courts have been central in American popular culture during the last century and point out how comfortable Americans are with the courtroom as cultural convention. In section three, I explore the impact of court-related popular culture on what Americans think of and expect from their courts. In the conclusion, I suggest a few steps that could be taken to limit popular culture's impact.

\section{What IS POPUlaR CUlTURE?}

Ray B. and Pat Browne have argued that when it comes to studying "popular culture," an academic undertaking they helped to initiate, "[a] clear and precise definition is necessary." Academic fields such as anthropology, communications, history, literature, psychology, religion, and sociology have all turned their attention to "popular culture," but each field has developed its own understanding of the core concept. ${ }^{5}$ In addition, everyday citizens often attach a wide range of meanings to

* Professor of Law, Marquette University School of Law; A.B. Harvard College; J.D. Yale Law School; Ph.D. in American Studies, University of Michigan.

1. See Patricia D. Marks, Do Courtroom Scenes Have Real-Life Parallels, 73 N.Y. ST. B.A.J. 40 (2001).

2. Id. at $40-42$.

3. Id. at 42 .

4. Introduction to The Guide to United States Popular Culture I (Ray B. Browne \& Pat Browne eds., 2001).

5. Id. For considerations of the various ways "popular culture" might be understood, see generally James CuRRaN \& Michael GuREvitch, MASS MEdia AND SOCIETY (3d ed. 2000); KeVIN LAUSE ET AL., POPULAR CULTURE: AN INTRODUCTORY TeXT(Jack Nachbar \& Kevin Lause eds., 1992); and JOHN STOREY, AN INTRODUCTORY GUIDE TO CULTURAL THEORY AND POPULAR 
"popular culture," and without some agreement about what the core subject is, "misunderstandings and frustrations might result."

For purposes of this essay, 1 define popular culture as cultural commodities and experiences produced by the culture industry and marketed to mass audiences. The definition designates something much more specific than just "the popular." If you enjoy the activities of jogging in the park in the morning or making a special salad for the family at dinner, these are good and healthy undertakings. Certain of the garb you might wear while jogging and books on salad-making might fit within my definition of popular culture, but the jogging and salad-making in and of themselves are not commodities and experiences produced by the culture industry for mass audiences. As "popular" as these activities might be, they do not qualify as "popular culture."

The three elements of my definition are products, industry, and audience. Products that we might characterize as "popular cultural" were available to consumers in Europe and in the American colonies as early as the 1600 s, but Jim Cullen, the leading historian of American popular culture, points to the final decades of the nineteenth century as the period during which "culture became an industry in the modern sense of the word." The most diversified and highly marketed pop cultural production of the early culture industry was literary, but in the course of the twentieth century, films, radio programs, recorded music, and television shows also flooded into the marketplace. In the present, products in different media remain distingnishable from one another, but it is the rare product that strikes a major chord in one medium without then being reproduced in second, third, and even fourth media. ${ }^{8}$

Pop cultural products do not just bubble up from the populace, but rather come from a large, sophisticated, and, of course, profit-driven industry. This industry employs literally thousands of writers, actors, technicians, marketers, and production workers. A handful of its "stars" are bigger than life, but almost all culture-industry workers, like most American workers, earn their livings in hierarchical and bureaucratic work arrangements. The industry's marketing personnel sell the pop cultural products in not only domestic markets but international ones as well. In fact, works of popular culture are among the United States' most important international commodities. Pop cultural products are the second largest net export of tbe United States after defense-industry products. ${ }^{9}$ One reads frequently of industry concerns about stealing of American popular culture with an eye to selling it abroad, and in fact "there is a lucrative trade in pirate tapes of American movies and music from Kathmandu to Hong Kong."

Culture (1993).

6. BROWNE \& BROWNE, supra note 4, at 1.

7. Jim CULlen, The ART of Democracy: A CONCISE History of Popular Culture IN THE UNITED STATES 90 (1996).

8. The famous Scopes trial from 1925 provided an engaging narrative that led to pop cultural products in a string of media. The original trial was the first to ever be broadcast nationally on radio. Later, in fictionalized form, the trial became Inherit the Wind, a highly successful Broadway play by Jerome Lawrence and Robert E. Lee. The play in turn was adapted in 1960 for the equally successful United Artists film of the same name starring Spencer Tracy, Fredric Marsh, and Gene Kelly.

9. Harry Hillman Chartrand, International Cultural Affairs: A Fourteen Country Survey, 22 J. Arts Mgmt. Law \& SoC'y 134 (1992) (citing Meet the New Media Monsters, THE ECONOMIST, Mar. 11, 1989, at 65).

10. Jack Miles \& Douglas McLennan, In-Country: The Battle for National Cultures: Global Crossing, Part II, ARTS J., Aug. 18, 2006, http://www.artsjournal.com/artswatch/ 
what seems to be an ambivalence about the pirating of pop cultural works in China, some have argued that the Chinese have, in reality, decided to steal from the American culture industry instead of subsidizing the production of domestic pop cultural commodities."

Do the commodities and experiences produced by the culture industry have an impact on their audiences? Commentators have long assumed that the answer to that question is yes. At the end of the nineteenth century, moralistic reformers including but not limited to Anthony Comstock worried that popular adventure stories and romance novels were corrupting readers, especially young ones. ${ }^{12}$ Comstock himself even attempted to suppress performances of George Bernard Shaw's Mrs. Warren's Profession on the theory that the play would make Americans sympathetic to prostitutes.

Since World War 1I, few have taken pop literature or drama to be the nation's chief corrupting influence, but criticisms of television's impact started almost as soon as primetime network broadcasting in the late I940s. The Southern Baptist Convention, for example, launched protests in the 1970s about tbe CBS sitcom Maude. The group claimed the show's episodes touching on abortion would lead viewers to have them. ${ }^{13}$ Catholic groups felt the series Soap would give viewers the wrong impression of priests, and in response to the criticism scriptwriters dropped an episode in which a Jesuit priest was to be seduced by the daughter of one of the series's lead characters. ${ }^{14}$

The problem with criticizing popular culture's impact, meanwhile, is that it is extremely difficult to gauge the impact of a particular pop cultural work or even a given type of work. Can we isolate the cause of the supposed impact? On whom does the impact fall? Do we have in mind the population as a whole, or are we willing to segregate parts of the public by age, gender, race, region, or whatever? How often must somebody listen to a type of music or watch a particular variety of television show? And, most fundamentally, what constitutes "impact," and how do we measure it? We live in a complex, sometimes contradicted, postmodern society that is interconnected with other societies all around the globe. Cultural forces are changing, swirling, and colliding. The socio-cultural context is almost tbe antithesis of a controlled laboratory environment in which cause and effect could be studied with some confidence.

One way around this immense problem-and an approach that has won favor with scholars of popular culture-is the consideration of a so-called "cultivation effect." Cultivation theorists argue that regular viewers of television programming or avid consumers of other varieties of popular culture come to see social reality differently. ${ }^{15}$ The argument is not so much that popular culture creates views of social reality but rather that popular culture prompts, encourages, and refines views of social reality. It is

aGlobalculture\%20-II.htm.

I1. Id.

12. See generally Paul S. Boyer, Purity In PRINT: THE Vice-Society Movement AND BOOK CENSORSHIP IN AMERICA (1968).

13. See James L. Baughmann, The Republic of Mass Culture: Journalism, FILMMAKING, AND BROADCASTING IN AMERICA SINCE I941, at 150 (3d ed. 2006).

14. Id.

15. See George Gerbner, Larry Gross, Michael Morgan, Nancy Signorielli, \& James Shanahan, Growing Up With Television: The Cultivation Processes, in MEDIA EFFECTS: ADVANCES IN THEORY AND RESEARCH 43, 46-47 (Jennings Bryant \& Dolf Zillman eds., 2d ed. 2002) and James Shanahan \& Michael MoRgan, TeleVision and Its Viewers: Cultivation THEORY AND RESEARCH (1999). 
most likely to do so when selected types of pop cultural works are viewed with some regularity by certain kinds of consumers. Genres, the standardized frameworks in which the great majority of pop cultural works come to rest, are important in this kind of research because they provide the repeating patterns that might arguably cultivate an effect. A cultivation effect, after all, would be virtually impossible to demonstrate with a unique, individualized work. As engaging as the work might be, it would not have the repetitive power anticipated for the cultivation of attitudes and impressions. But genre, and regular exposure to it, does have the potential to affect how generic devotees see their world. A fondness for and loyalty to a genre or other repetitive pop cultural patterns, the argument goes, have ramifications for readers' and viewers' perceptions.

The most extensive cultivation effect research involves the impact of television viewing on viewers' perceptions of crime and violence in the society around them. ${ }^{16}$ Researchers have shown that, regardless of falling crime rates in a given area, frequent television viewers contmue to believe that crime is rampant. ${ }^{17}$ More generally, evidence exists that heavy television-viewing leads to an exaggerated sense of how much violence there is in society. ${ }^{18}$

This cultivation-effect research regarding crime and violence reinforces the belief that contemporary popular culture is a cultural phenomenon of significant impact. While an individual consumer's reading of a trashy novel or viewing of a DVD from Blockbuster can be minimized as just harmless escape, the overall presence and power of popular culture should not be minimized. We need not man the barricades like the prudish Anthony Comstock or try to censor primetime television shows about abortion or lusty Jesuits, but we should be aware of the potential of popular culture to influence perceptions of and opinions about social life.

\section{Court-Related Popular Culture}

Since at least the $1830 \mathrm{~s}$, observers have noted the unusual importance of courts and courtroom proceedings in the United States. Alexis de Tocqueville, a minor French aristocrat asked by his country to report on developments in the United States, thought American courts were "the most obvious organs through which the legal body influences democracy." 19 A judge, de Tocqueville thought, had "high social standing among his equals."20 Jury duty in his opinion "instill[ed] some of the habits of the judicial mind into every citizen, and just those habits are the very best way of preparing people to be free."21 While the social and political weightiness of American courts may have surprised de Tocqueville and his French readers, the Americans he met during his tour of the Republic were most likely nonplussed about the phenomenon.

Given the importance of courts in American life, it is hardly surprising that the modern culture industry which emerged toward the end of the nineteenth century

16. For a review of several dozen studies in this area, see Sarah Eschholz, The Media and the Fear of Crime: A Survey of the Research, 9 U. FLA. J.L. \& PUB. POL'Y 37 (1997).

17. See id. at 37-39.

18. Gerbner et al., supra note 15 , at 52.

19. AleXis DE TOCQUeVIlle, Democracy IN AMERICA 269 (J.P. Mayer ed., George Lawrence trans., Anchor Books 1969) (1835).

20. $I d$.

21. Id. at 274. 
routinely included trials and other courtroom proceedings in certain of its products. Popular culture might transport its readers, listeners, and viewers to distant times and faraway lands. Lots of popular culture is simply fantasy. But modern popular culture is also sometimes "realistic" in a stylized way and draws on the institutions and settings of the society that spawns it. Americans were relatively familiar with their courts and courtroom procedures and took them to be important, and producers of popular culture almost unthinkingly included them in their products.

Two early examples of court-related popular culture, one literary and the other cinematic, illustrate the point. In the realm of cheap literature, Randolph Mason was America's most recognizable pop cultural lawyer at the turn of the twentieth century. The creation of West Virginia writer Melville Davisson Post, Mason appeared in dozens of stories in popular magazines and hardcover collections. Frequently, Mason won victories for his clients in tense, surprising courtroom proceedings. ${ }^{22}$ One of the first law-related films produced in America was D.W. Griffiths' Falsely Accused! (1908). The film concludes with a dramatic courtroom proceeding in which a devoted boyfriend actually screens a primitive film in court in order to exonerate the love of his life from murder charges. ${ }^{23}$ In literature and film, Americans took easily and comfortably to the fictionalized, dramatic courtroom scenes.

This comfort with the courtroom in popular culture continued throughout the twentieth century; indeed, some of the most recognizable works of American popular culture froin the middle decades of the twentieth century revolved around dramatic courtroom proceedings. Such classic films from the 1950s as 12 Angry Men (1957), Witness for the Prosecution (1957), I Want To Live (1958), Anatomy of a Murder (1959), The Young Philadelphians (1959), and Compulsion (1959) concern and/or portray courtroom proceedings, and To Kill A Mockingbird (1962), one of the bestloved films in all of cinema history, of course features Atticus Finch's stirring, albeit unsuccessful, defense of Toin Robinson at trial. ${ }^{24}$ America's best-known pop cultural lawyer of the 1950s and 1960s was Perry Mason. Portrayed by the actor Raymond Burr, Perry Mason appeared weekly in a primetime series on CBS from 1957-66. In the typical hour-long episode Mason exonerated his client and identified the perpetrator with the denouement occurring in a dramatic courtroom proceeding. Customarily left behind by Mason's quick thinking and numerous strategic moves, viewers could at least take comfort in the obligatory postscript in which Mason explained to his loyal secretary Della Street, played by Barbara Hale, how in the world he figured everything out. ${ }^{25}$

22. For a consideration of Melville Davisson Post's Randolph Mason stories and other works, see Francis M. Nevins, From Darwinian to Biblical Lawyering: The Stories of Melville Davisson Post, 18 LEGAL STUD. F. 177, 182-85 (1994).

23. For a discussion of Falsely Accused!, see Carol J. Clover, God Bless Juries!, in Refiguring AMERICAN Film GenRes: History aND Theory 255, 257-58 (Nick Browne ed., 1998).

24. I critiqued the important law films of the 1950s and also To Kill A Mockingbird in Law, Cinema, and Ideology: Hollywood Legal Films of the I950s, 48 UCLA L. REv. 1473 (2001).

25. Book-length studies of Erle Stanley Gardner and the Mason stories include J. DENN1S BOUNDS, PERry MASON: THE AUthorship and Reproduction of A POPUlar Hero (1996); FRANCIS L. \& ROBERTA B. FUGATE, SECRETS OF THE WORLD'S BEST-SELLING WRTER: THE STORY Telling TeChNiques of Erle Stanley Gardner (1980); and Dorothy B. Hughes, Erle Stanley Gardner: The Case of the Real Perry Mason (1978). 
During the last twenty years, courts and courtroom proceedings have continued to be staples in some of our most successful popular culture. Excellent dramatic films such as The Accused (1988), A Few Good Men (1992), and Philadelphia (1993) featured courtroom proceedings, as did hilarious comedies such as My Cousin Vinny (1992), Liar Liar (1997), and Legally Blonde (2001). On television, heroic solo practitioners such as Perry Mason have been supplanted by complex, often alienated lawyers working in law firms and district attorneys' offices. However, such shows as L.A. Law (1986-94), Ally McBeal (1997-2002), and The Practice (1997-2004), as well as the current Law \& Order (1990-present) and Boston Legal (2004-present), still include courtroom proceedings in virtually every episode.

Often, judges and experienced litigators find it impossible to enjoy court-related popular culture because it seems to them so unfaithful to what really happens in our courtrooms, and, indeed, important differences do exist between the average pop cultural courtroom proceeding and most real ones. I had the opportunity in the late 1990 s to discuss the differences in criminal trials with a half dozen Indiana trial court judges whom 1 had met while lecturing in the Indiana Graduate Program for Judges. ${ }^{26} I$ included a discussion of the differences in an article I published on pop cultural courts and courtroom proceedings. ${ }^{27}$

The differences include not only purported procedures and practices in the courtroom but also the whole manner in which things ultimately fit together or fail to fit together. As for procedures and practices, opening statements in pop culture are much more provocative than they are in actual courtrooms. Evidence is more striking, and examinations and cross-examinations are more elaborate and aggressive. Sidebar conferences among the judge and the attorneys are very common in popular culture but much less so in actual courtrooms. Judges do not like to sort out evidentiary and procedural matters in front of a jury, but if a judge goes to chambers with the attorneys, jurors have the distressing tendency to disappear to the restrooms, wander off, and, on occasion, head home. In pop cultural proceedings, defendants almost always take the stand, but in actual courtrooms most do not. Closing arguments are very dramatic in the pop cultural courtroom, and the camera often looks into the faces of the attorneys from over the shoulders of the jurors, making the film and television viewers feel at least momentarily like they are in the jury box. In the end, defendants in the real world are much more likely to be found guilty than they are in popular culture.

In addition to all of the differences noted above, more subtle differences exist in the ways things fit together. In pop cultural trials almost every statement, piece of evidence, or witness becomes part of the whole. There are exceptions of course, and some pop cultural works leave readers and viewers wondering what happened. But, in general, pop cultural works have a clear narrative direction and provide a sense of closure.

These characteristics reminded Professor AIan Dershowitz of Chekhov's advice to the would-be playwright. ${ }^{28}$ Chekhov told the playwright that if a character hangs a gun

26. I discussed these matters with the Honorable Lorenzo Arredondo, Cynthia Ayers, David Dreyer, Ruth Reichard, and Ted Todd.

27. David Ray Papke, The American Courtroom Trial: Pop Culture, Courthouse Realities, and the Dream World of Justice, 40 S. TEX. L. REV. 919, 920-30 (1999).

28. See Alan M. Dershowitz, Life is Not a Dramatic Narrative, in LAW's STOR1ES: NARRATIVE AND RHETORIC IN THE LAW 99, 99-100 (Peter Brooks \& Paul Gewirtz eds., 1996). 
on the wall in the first act of a play, one character or another had best use it by the third act. ${ }^{29}$ Comparable advice could be given to the screenwriter for a pop cultural trial. When striking evidence or pointed testimony is presented, it should count for something in the end.

In real-life trials, by contrast, irrelevant actions and testimony, randomness, purposelessness, and delay abound. Recalling Chekhov, guns are hanging on the walls, and nobody appears likely to use them. This is not necessarily a problem. The goal in an actual trial, after all, is not narrative coherence or closure but rather a just and correct result. The latter is often messy and imperfect.

None of the differences between pop cultural and actual courtroom proceedings, I hasten to add, seem to trouble lay Americans as much as they do judges and litigators. The average adult American routinely normalizes courtroom scenes from cheap fiction, film, and television; he or she easily brings the courtroom scene within his or her ken. When Americans read about, listen to, or watch popular courtroom drama, it all makes perfectly good sense to them. We appreciate pop cultural courtrooms as not only places that determine guilt and innocence but aIso sources of lessons about life in general. The courtroom is one of our most familiar and best-liked cultural conventions. ${ }^{30}$

\section{GAUGING THE IMPACT OF COURT-RELATED POPULAR CULTURE}

Given the large amount of court-related popular culture and the way lay Americans easily bring this material within their perception and understanding, we might reasonably expect court-related popular culture to have an impact. We might anticipate that court-related popular culture would affect what Americans want and expect from their real-life courts. We might even wonder if the popular culture could alter Americans' sense of what constitutes justice and whether it is likely to be achieved in our system.

Different observers in different eras have surely argued that court-related popular culture affects actual proceedings. In the middle decades of the twentieth century, commentators alleged that the previously mentioned Perry Mason had an impact. When commentators Charles and Mariann Pezella Winnick complained about the way pop cultural lawyers-but surely not actual ones-were able to extract confessions from witnesses on the stand, they had Perry Mason first in mind. ${ }^{31}$ The distinguished and highly successful trial lawyer Edward Bennctt Williams complained that Mason's resourcefulness and inevitable victories created unrealistic expectations among defendants. The very best criminal defense lawyers, Williams said, are fortunate if they can prevail in a bare minimum of their trials. ${ }^{32}$

In the present, comparable complaints have been heard from the prosecutor's side regarding the three current $C S I$ series on primetime television. The series feature

29. Id.

30. M. H. Abrams defines conventions as "conspicuous features of subject matter, form, or technique that occur repeatedly in works of literature." M. H. ABRAMS, A GLOSSARY OF LITERARY TERMS 47 (7th ed. 1999). Conventions are perhaps even more important in popular culture than in literature per se.

31. Charles Winick \& Mariann Pezzella Winick, Courtroom Drama on Television, J. of Coмm., Fall 1974, at 67, 73.

32. See Edward Bennett Williams, The High Cost of Television's Courtroom, 3 TELEvISION QUART. 11, 13 (1964). 
attractive and resourceful crime scene investigators who are able to use highly sophisticated forensic evidence to identify the true perpetrators of crime, usually just before the end of the hour. Jurors in real-life trials, it is alleged, have come to expect comparable evidence. ${ }^{33}$ In particular, those who watch CSI take DNA evidence to be incontrovertible and also readily available. ${ }^{34}$ They also allegedly have come to attach less significance to witnesses' testimony, science rather than human memory being the key in their minds to reliable prosecutions. ${ }^{35}$ If a district attorney failed somehow to present the DNA left on the bullet casings found at the scene of the crime, the argument goes, a real-life jury consisting of regnlar CSI viewers would be unlikely to convict.

Beyond impressions, various scholars have attempted to gauge the impact of lawrelated popular culture on what Americans think of their legal institutions. Kimberlianne Podlas investigated the effects of frequent viewing of simulated daytime courtroom shows on men and women called for actual jury service. ${ }^{36}$ Victoria S. Salzmann and Philip T. Dunwoody surveyed beginning law students to see if popular culture had affected their perceptions of the legal profession. ${ }^{37}$ Putting an international spin on the same question that engaged Salzmann and Dunwoody, eight scholars studied the impact of popular culture on law students' perceptions of lawyers in countries stretching from Australia and Argentina to the United States and the United Kingdom and then to Germany. ${ }^{38}$

The most important of these studies for purposes immediately at hand is the one conducted by Professor Podlas. Her concern - the impact of daytime simulated courtroom shows-is more important than non-viewers of daytime television would guess. A dozen of these syndicated shows currently appear, and in some areas it is possible to literally watch such programming throughout the day. ${ }^{39}$ The most famous of the shows is Judge Judy, featuring former New York City family court judge Judith Sheindlin pontificating and preening for her audience. Other shows range from the venerable The People's Court to the mildly bizarre Moral Court. The former once featured Judge Joseph Wapner. ${ }^{40}$ His grandfatherly dignity attracted a large audience in the $1980 \mathrm{~s}$, but the current tone of the show is different. The presiding judge is Cuban American Marilyn Milian, and advertisements for the show describe Milian as the

33. Karin H. Cather, The 'CSI' Effect: Fake TV and Its Impact on Jurors in Criminal Cases, THE ProseCuTOR Mar.-Apr. 2004, at 9.

34. See Julie Hilden, How TV Shows Depict Lawyers and Legal Process, CNN LAW CENTER, Nov. 1 I , 2004, http://www.cnn.com/2004/LAW/1 1/I 1/hilden.tv.lawyers/index.html. 35. See id.

36. Kimberlianne Podlas, Please Adjust Your Signal: How Television's Syndicated Courtrooms Bias Our Juror Citizenry, 39 AM. BUs. L.J. 1 (2001).

37. Victoria S. Salzmann \& Philip T. Dunwoody, Prime-Time Lies: Do Portrayals of Lawyers Influence How People Think About the Legal Profession?, 58 SMU L. REv. 411 (2005).

38. Michael Asimow et al., Perceptions of Lawyers - A Transnational Study of Student Views on the Image of Law and Lawyers, 12 INT. J. LEGAL PROF. 407 (2005).

39. For a critical examination of these shows, see Michael M. Epstein, Judging Judy, Mablean and Mills: How Courtroom Programs Use Law to Parade Private Lives to Mass Audiences, 8 UCLA ENT. L. REv. 129 (2001).

40. See Helle Porsdam, Law as Soap Opera and Game Show: The Case of "The People's Court, " in LEgally SPEAKING: CONTEMPORARY AMERICAN CULTURE AND THE LAW 89 (1999). 
"hottest judge on daytime television." In Moral Court Judge Larry Elder presides. He wears a billowy graduation robe and awards various amounts depending on whether a "litigant" can show the other party to be morally wrong, offensive, or outrageous. The setting is a pseudo-courtroom, but Moral Court has the feel of a game show.

Podlas no doubt appreciated that shows such as Judge Judy and Moral Court were ideal for a cultivation-effect study. The shows offer standardized and frequent drilling in the workings of something that looks like a court. Some people watch these shows hour after hour, day after day. Dashka Slater, writing in Legal Affairs, did just that and dubbed herself and other comparable viewers not "couch potatoes" but rather "court potatoes. ${ }^{, 41}$ The regular viewing of generic programming, as suggested earlier, might "cultivate" perceptions and attitudes.

In her study, Podlas surveyed 241 jury duty respondents in Manhattan, New York; Hackensack, New Jersey; and Washington, D.C. On the basis of their survey responses, Podlas divided the jury-pool members into two groups: frequent viewers and infrequent/non-viewers. People in the latter category watched the simulated courtroom shows once a week or less. A large majority of those polled, it turned out, were frequent viewers. ${ }^{42}$ On average, the frequent viewers believed judges should be active, opinionated directors of courtroom proceedings. ${ }^{43}$ Especially intriguing was Podlas's finding that prior court experience did not substantially affect potential jurors' opinions. ${ }^{44}$ When all was said and done, the viewing of daytime television was more important than exposure to real-life courts in the shaping of what those polled expected of their courts.

We cannot make too much of this study. It involves only one type of popular culture. Those surveyed were no doubt thinking more critically about how courts should work than average unreflective citizens would. But still, the findings of the study undertaken by Podlas are sobering. Popular culture appears to cultivate a judgecentered vision of the courtroom proceeding rather than valorizing representation by counsel, a jury of one's peers, and carefully observed procedural rules. Popular culture seems to endorse a type of courtroom proceeding that is detectably authoritarian and includes intense moral condemnation from the men and women in charge, that is, the judges.

\section{CONCLUSION}

Should something be done to reduce the impact of court-related popular culture on Americans' views of the courts and courtroom proceedings? The question is a serious one for not only judges and courthouse administrators but also for the public as a whole. In the America de Tocqueville observed in the 1830s, as well as today, courts and courtroom proceedings play a major role in our self-definition as a people. The image of the trial may in fact be the most important civic image in the dominant ideology. If the ubiquitous pop cultural portrayals of courtroom proceedings inculcate

41. Dashka Slater, Court Potato, Legal AffaIRS, May-June 2002, at 9.

42. Podlas, supra note 36 , at 11 . This result is not surprising since jury pools include disproportionate numbers of people who are unemployed or retired. Presumably, these same groups would be more likely to be daytime television viewers.

43. Id. at 11-13.

44. Id. at 14. 
troubling attitudes and expectations, we should be prepared to take steps to guard against this development.

1 have three ideas regarding the phenomenon. They concern what can be done in the courthouse, in the community, and in the den and family room. The first two of my ideas have occurred to others and have to some extent been acted upon. My third idea is the most difficult but perhaps the most important in the long run.

With regard to practices and procedures in real-life courthouses, we need to be mindful of the possible impact of popular culture on jurors and tailor instructions to jury pools and questions in voir dire accordingly. The Honorable Patricia D. Marks, with whom this essay began, uses clear instructions and careful questions to make sure jurors in her courtroom are not unduly influenced by popular culture and to excuse those potential jurors who cannot grasp the differences between pop cultural courts and real ones. ${ }^{45}$ The Honorable Jacqueline Connor of the California Supreme Court, Los Angeles County, would certainly agree. "As members of the legal community," she argues, "we have an obligation to ensure the accuracy of public perceptions of "courtroom reality.",46

In the community as opposed to the courthouse, lawyers, courthouse personnel, and especially judges should be much more systematic in teaching the general public how the courts work. Many judges of course already speak regularly to school and community groups, but to an even greater extent public education could be recognized as a formal duty of the bench. In explaining how the courts work, judges could be especially determined to distinguish actual courts from those in the cinema and on television.

And finally, I think Americans have to approach their popular culture more critically. After a hard day at the office or around the home, many of us just want popular culture to wash over us, removing our frustrations and disappointments and allowing us to escape, but, given the pervasiveness and influence of popular culture, this attitude is dangerous. Educators should teach us how to challenge our popular culture, and we should take those lessons to heart. When we are watching a television show or a DVD in our dens and family rooms, we should intellectually wrestle with what we are watching. Popular culture can actually be more entertaining and edifying if we critically examine it. And, furthermore, "court potatoes"-mindless consumers of court-related popular culture-do not make particularly valuable jurors and citizens or especially interesting colleagues and friends.

45. Marks, supra note 1 , at 42 .

46. Jacqueline Connor \& Anne Endress Skove, Dial " $M$ " for Misconduct: The Effect of Mass Media and Pop Culture on Juror Expectations, in FUTURE TRENDS IN STATE COURTS 2004 104, 105 (Carol R. Flango, Neal Kauder, Kenneth G. Pankey, Jr. \& Charles Campbell eds. 2004). 